the Chairman, Professor Joseph H. Greenberg, Committee on African Studies, Stanford University, Stanford, California 94305.

\title{
African Studies at Haverford College, Pennsylvania
}

A CENTRE of African studies has been established at Haverford College under the directorship of Dr. Harvey Glickman, associate professor of political science. A seminar has been held on 'African civilization: its traditions and transformations', at which Dr. David Apter spoke on 'Political innovation in Africa'. Other speakers and guest lecturers included Dr. Robert Lystad, Dr. Roy Sieber, and Dr. Alan P. Merriam. The character of emergent political systems, social restratification, economic development, the rediscovery of African history, and artistic and literary manifestations were discussed, and several joint sessions with African and American students from Lincoln University are planned.

\section{'Sierra Leone Studies'}

Sierra Leone Studies, the Journal of the Sierra Leone Society, which has not appeared since I 963 (New Series, No. I7) has recommenced publication on a twice-yearly basis under the editorship of Michael Crowder, the Director of the Institute of African Studies, Fourah Bay College, the University College of Sierra Leone. Its Assistant Editor is J. G. Edowu Hyde, the Secretary of the Institute.

The journal will be issued twice yearly, dated January and July. The January 1966 issue included articles on 'Africanus Horton and the Idea of Independence in West Africa' by Robert July, 'Traditional Concepts of Mental Health in Sierra Leone' by J. M. Dawson, 'Sierra Leone's Largest Provincial Town' by Milton Harvey, and 'The Spelling and Connotation of the Toponym "Sierra Leone" since $\mathrm{r}_{46 \mathrm{r}}$ " by P. E. H. Hair. The 'Notes' included H. L. Van de Laan's ' Notes on the Statistical Documentation on the Economy of Sierra Leone '. The book reviews cover especially recent books of interest to Sierra Leone.

The subscription rate is Le 2 (U.K., £I; U.S., \$2.80) a year and Le I (U.K., Ios.; U.S., $\$ 1.40$ ) per copy including postage. Back numbers of the New Series, Nos. I to I 7 , are available at 50 c. (U.K. ss.; U.S., 70 c.) per copy including postage. The Johnson Reprint Corporation of I I Fifth Avenue, New York, U.S.A., is reprinting out-of-print copies of the journal, in particular the Old Series. All correspondence should be addressed to the Business Manager, Errol Magidson, c/o Institute of African Studies, Fourah Bay College, Freetown, Sierra Leone.

\section{'The Sudan Research Information Bulletin'}

THE first number of this bulletin, published by the Sudan Unit (Director Yusuf Fadl Hasan), contains information concerning research into subjects of special Sudanese interest in progress at the University of Khartoum. The bulletin hopes to provide a comprehensive information service on the progress of Sudanese studies throughout the world. Information should be sent to: The Director, Sudan Unit, Faculty of Arts, University of Khartoum, P.O. Box 321, Khartoum, Sudan.

\section{'Journal of Asian and African Studies'}

THE new quarterly Journal of Asian and African Studies is issued in January, April, July, and October, starting with January I966. It presents specialized studies in the sociology of the developing nations of Asia and Africa, and is edited by $\mathrm{K}$. Ishwaran, of York University, Toronto, in conjunction with a world-wide board of specialists. The journal is published by $\mathrm{E}$. J. Brill of Leiden; the subscription price per volume of four issues ( $c .300$ pages) is 43 guilders. 